\title{
1-Naftalen-2-il-etanon-o-propil-oksimin Kuantum Kimyasal Çalışmaları
}

\author{
İlhan Küçük, Yunus Kaya ${ }^{1 *}$ \\ Geliş / Received: 12/10/2019 \\ Revize / Revised: 10/12/2019 \\ Kabul / Accepted: 23/12/2019 \\ ÖZ
}

Bu çalışmada, biyolojik aktif özellik gösterebilen 1-naftalen-2-il-etanon-O-propil-oksim (NEOPO) molekülünün kuantum kimyasal özellikleri, yapısal, spektroskopik, elektronik ve moleküler yerleştirme olarak sunulmuştur. Tüm kuantum kimyasal çalışmalar B3LYP / 6-311 ++ G (d, p) yöntem ve temel seti ile yoğunluk fonksiyonel teorisi (DFT) ile gerçekleştirilmiştir. Spektroskopik özellikleri, atom yükleri, HOMO-LUMO moleküler orbitalleri, kimyasal reaktivite ve moleküler elektrostatik potansiyeli (MEP) teorik olarak araştırılmıştır. Spektroskopik özellikler deneysel olarak desteklenmiştir. Ayrıca, moleküler yerleştirme çalışmaları için Autodock / Vina programı kullanılmış ve bağlanma serbest enerjileri DNA-molekül ve protein-molekül etkileşimleri için sırasıyla $-27.20 \mathrm{ve}-34.73 \mathrm{~kJ} /$ mol olarak hesaplanmıştır.

Anahtar Kelimeler-Oksim Eter, Kuantum Kimyasal Hesaplama, IR, NMR ve UV-Gör. Bölge Spektrumlart, Moleküler Yerleştirme

\footnotetext{
1*Sorumlu yazar iletişim: yunus.kaya@btu.edu.tr (https://orcid.org/0000-0001-7228-2340) Department of Chemistry, Bursa Technical University University, Bursa, Turkey. iletişim: ilhankucuk91@gmail.com (https://orcid.org/0000-0002-1712-0063) Department of Chemistry, Bursa Technical University University, Bursa, Turkey.
} 


\title{
Quantum Chemical Studies of 1-Naphthalen-2-yl- ethanone-o-propyl-oxime
}

\begin{abstract}
In this work, quantum chemical properties of 1-naphthalen-2-yl-ethanone-O-propyl-oxime (NEOPO) molecule which may be biologically active have been presented as a structural, spectroscopic, electronic and molecular docking. All quantum chemical studies were performed by density functional theory (DFT) with the B3LYP / 6$311++G(d, p)$ method and basis set. The spectroscopic properties, atomic charges, HOMO-LUMO molecular orbitals, chemical reactivity and molecular electrostatic potential (MEP) were investigated as theoretically. The spectroscopic properties have been supported as experimentally. In addition, the Autodock/Vina program was used for molecular docking studies and the binding free energies were calculated as -27.20 and $-34.73 \mathrm{~kJ} / \mathrm{mol}$ for DNA-molecule and protein-molecule interactions, respectively.
\end{abstract}

Keywords- Oxime Ether, Quantum Chemical Calculation, IR, NMR and UV-Vis Spectra, Molecular Docking 


\section{INTRODUCTION}

Oxime ether molecules which have $-\mathrm{C}=\mathrm{N}-\mathrm{O}-\mathrm{R}$ group, are simply synthesized from the reaction of oximes with corresponding alkyl group. Such molecules are of great interest in medicine because of their biological activity [1-3]. Therefore, many researchers have been working with these molecules for over a hundred year. On the other hand, the Density Functional Theory (DFT) has attracted considerable attention due to its great precision in the theoretical calculation of the molecular and spectroscopic properties [4-6]. To the best of our knowledge, no experimental and DFT studies on synthesis, conformational, spectroscopic, electronic, physicochemical and molecular docking properties of NEOPO molecule have been reported so far. Therefore, a detailed conformational and optimized structure, IR, NMR and UV-vis. spectra, HOMO-LUMO energy band gaps, MEP, and thermodynamic properties of NEOPO molecule were performed at the DFT/B3LYP method with $6-311++\mathrm{G}(\mathrm{d}, \mathrm{p})$ basis set. In addition, the molecular docking properties were investigated to explain the interaction of NEOPO with DNA and protein using Autodock/Vina software.

\section{EXPERIMENTAL AND COMPUTATIONAL METHOD}

All chemicals used in this investigation were purchased commercially and used without any purification. FT-IR spectrum for the title compound was recorded on a Perkin Elmer Spectrum Two FT-IR spectrophotometer. The NMR spectra were performed in DMSO-d6 solvent on a Varian Infinity plus spectrometer. UV-vis spectrum was obtained by using an Agilent Cary60 spectrophotometer at room temperature. The compound solved in EtOH was verified with spectral bandwidth $2 \mathrm{~mm}$ and quartz cell $1 \mathrm{~cm}$ for electronic transitions. The NEOPO molecule was synthesized according to the literature [7]. The NEOPO was prepared by refluxing a mixture of $41.60 \mathrm{mmol} 2$-acetonaphthone $(7.08 \mathrm{~g}), 49.92 \mathrm{mmol}$ hydroxylamine hydrogen chloride (2.75 g) and $49.92 \mathrm{mmol}$ propyl chloride ( $3.92 \mathrm{~g}$ ) in $25 \mathrm{~mL}$ DMSO and $10 \mathrm{~mL} \mathrm{H}_{2} \mathrm{O}$ solution, and $1.00 \mathrm{~g}$ $\mathrm{KOH}$ are mixed in a flask. The reaction mixture was stirred for $2 \mathrm{~h}$ under reflux at $60{ }^{\circ} \mathrm{C}$. The reaction was monitored by TLC. The oily result was extracted between ethyl acetate $(80 \mathrm{~mL})$ and brine $(20 \mathrm{~mL})$ followed three times and after the ethyl acetate was evaporated, the yellow oily NEOPO compound was obtained in \%86 yield. IR, ${ }^{1} \mathrm{H}$ NMR and ${ }^{13} \mathrm{C}$ NMR spectra confirmed the molecule. For NEOPO, Mw: $227.307 \mathrm{~g} \cdot \mathrm{mol}^{-1}$ $\left(\mathrm{C}_{15} \mathrm{H}_{17} \mathrm{NO}\right)$. (FT-IR, ATR): $v\left(\mathrm{~cm}^{-1}\right) 3055 \mathrm{~s}, 3018 \mathrm{vw}, 1676 \mathrm{~s}, 2965 \mathrm{~s}, 2886 \mathrm{~m}, 1483 \mathrm{~s}, 1461 \mathrm{~s}, 1379 \mathrm{~s}, 1235 \mathrm{~m}, 1068 \mathrm{~s}$, 997s, 973m, 926s, 770m, 517s. ${ }^{1} \mathrm{H}$ NMR (DMSO-d6, $\delta$ (in ppm): 7.89 (q, 2H); 7.90 (m, 3H); 7.86 (t, 2H); 4.25 (t, $2 \mathrm{H}) ; 2.39(\mathrm{~s}, 3 \mathrm{H}) ; 1.83(\mathrm{~m}, 2 \mathrm{H}) ; 1.05(\mathrm{t}, 3 \mathrm{H}) .{ }^{13} \mathrm{C}$ NMR (DMSO-d6, $\delta($ in ppm ); 133.59;128.44; 127.64; 127.56; $127.51 ; 127.48 ; 127.38 ; 75.91 ; 22.41 ; 12.44 ; 10.51$.

All quantum chemical calculations were performed with the Gaussian 09 software packed [8] by using HP Z240 model workstation. The conformational analysis and optimized molecular geometry in gas phase, vibrational and NMR spectroscopy, electronic properties and some physicochemical properties such as the HOMO, LUMO, HOMO-LUMO energy gap, atomic charges, chemical reactivity, molecular electrostatic potential (MEP) and thermodynamic properties on the NEOPO were calculated using B3LYP method [9] with 6$311++\mathrm{G}(\mathrm{d}, \mathrm{p})$ basis set. Due to the known systematic errors, the calculations according to harmonic oscillator, incomplete treatment of electron correlation, the vibrational frequencies are usually calculated as larger than experimentally data [10]. For this reason, the calculated vibrational frequencies were scaled by 0.958 [11] for $4000-1700 \mathrm{~cm}^{-1}$ and 0.978 [12] for $1700-400 \mathrm{~cm}^{-1}$ ranges, respectively. The ${ }^{1} \mathrm{H}$ and ${ }^{13} \mathrm{C}$ NMR chemical shifts were performed by GIAO method (gauge-including atomic orbital method) based on optimized at the mentioned level in DMSO solvent for NMR calculations. The UV-vis spectrum in EtOH solvent was obtained using time dependent DFT method with the IEFPCM. Molecular docking studies for DNA and protein were calculated using Autodock/Vina program [13]. The crystal structures of B-DNA (PDB ID: 1BNA) and HSA (PDB ID: $1 \mathrm{H} 9 \mathrm{Z}$ ) were retrieved from the Protein Data Bank. The Autodock software was used for converting the PDB format of all out files. In addition, the Discovery Studio 3.5 software was used visualization of the docked systems. The binding sites were centered on the DNA and HSA, and a grid box was created with $60 \times 60 \times 60$ points and a $0.375 \AA$ grid spacing in which almost the entire macromolecules were involved. All other parameters were kept at their default values. 


\section{RESULTS AND DISCUSSION}

The E- and Z- isomerization of NEOPO molecule was calculated by using B3LYP/6-311++G(d,p) level, and the structure of these isomers are given in Figure 1(a). The energy of the $\mathrm{Z}$ isomer is higher than the energy of $\mathrm{E}$ isomer by $3.03 \mathrm{~kJ} / \mathrm{mol}$, this result indicates that the $\mathrm{E}$ isomer is more stable than $\mathrm{Z}$ isomer. In addition, the conformational analysis of the NEOPO was calculated by determining the potential energy surface (PES) around the dihedral angles $\mathrm{C} 9-\mathrm{C} 10-\mathrm{C} 12-\mathrm{N} 1(\alpha)$ and $\mathrm{C} 12-\mathrm{N} 1-\mathrm{O} 1-\mathrm{C} 13(\beta)$. The PES determined from rotation $\mathrm{C} 10-\mathrm{C} 12$ and N1-O1 bond are shown in Figure1 (b). The $\alpha$ and $\beta$ dihedral angles for NEOPO molecule were calculated as $159^{\circ}$ and $179^{\circ}$, respectively.

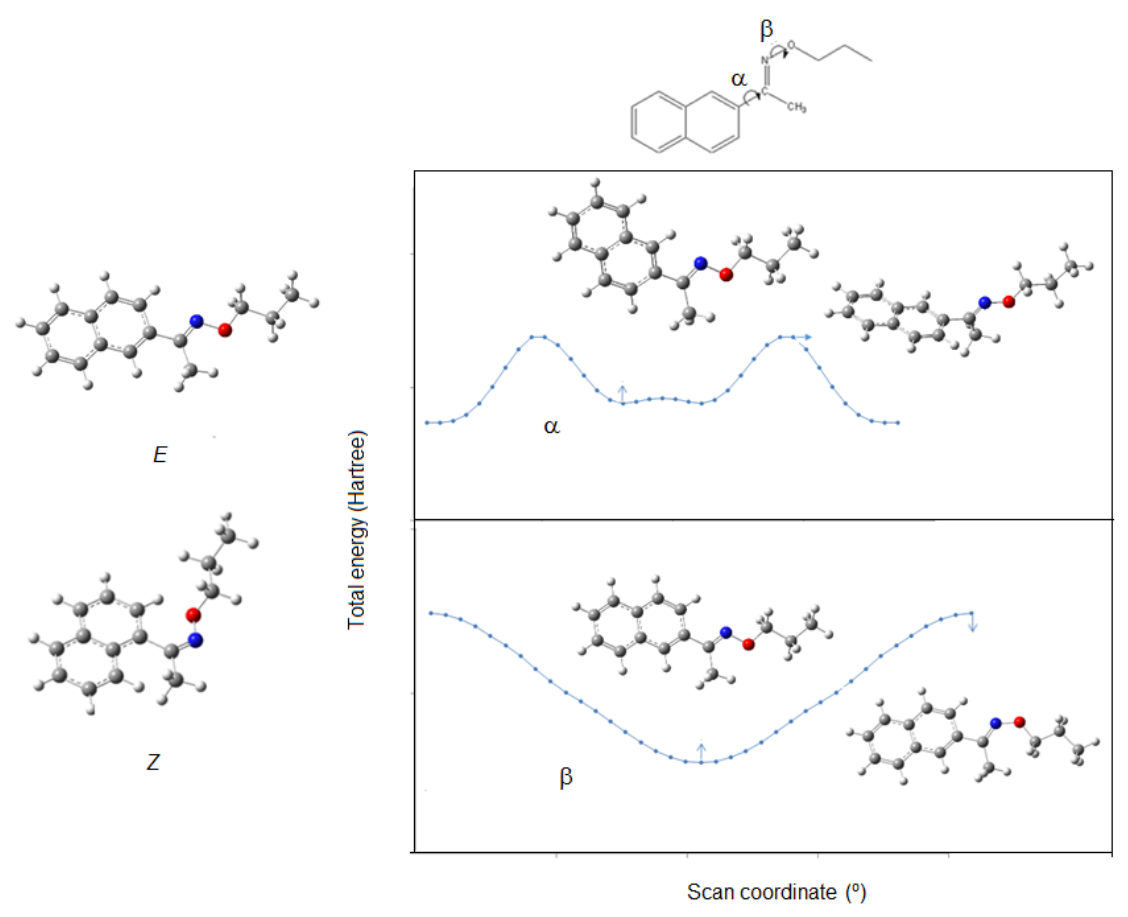

(a)

(b)

Figure 1. (a) $E$ - and $Z$ - isomers, (b) potential energy surfaces of NEOPO molecule

The most stable geometry of NEOPO molecule was optimized by using B3LYP/6-311++G(d,p) level is given in Figure 2 with their numbering of atoms. The average $\mathrm{C}-\mathrm{C}$ bond length of aromatic ring of NEOPO is $1.402 \AA$. Bond lengths of $\mathrm{C} 10-\mathrm{C} 12, \mathrm{C} 13-\mathrm{C} 14$ and $\mathrm{C} 14-\mathrm{C} 15$ were calculated $1.485,1.520$ and $1.532 \AA$, respectively. The most important bonds in the oxime molecules are $-\mathrm{C}=\mathrm{N}$ - and $=\mathrm{N}-\mathrm{O}$ - bonds, which are 1.287 and $1.392 \AA$, respectively. These calculated values are consistent with the reported results [14]. The C-C-C bond angles of naphthalene ring in the NEOPO molecule in range of 118.8-122.0 $0^{\circ}$ The oxime bond angles C12-N1$\mathrm{O} 1$ and $\mathrm{N} 1-\mathrm{O} 1-\mathrm{C} 13$ were calculated as 113.7 and $109.6^{\circ}$, respectively. 


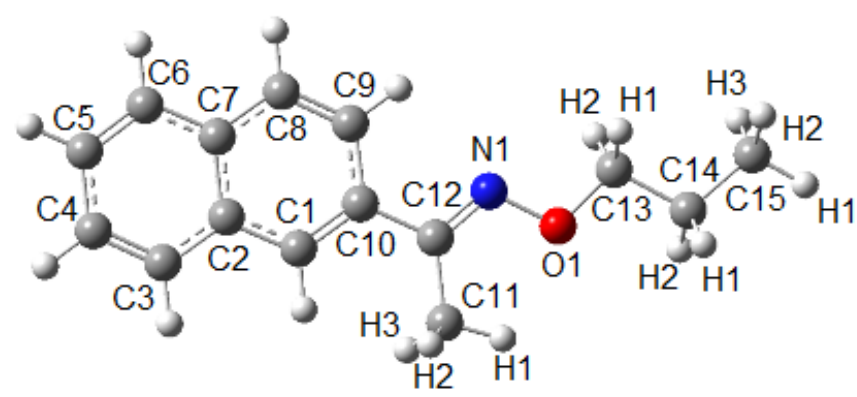

Figure 2. Optimized structures with atomic numbers of the NEOPO

Harmonic vibrational frequencies of NEOPO were calculated by employing B3LYP method with 6$311++\mathrm{G}(\mathrm{d}, \mathrm{p})$ basis set and compared with experimental values are presented in Figure 3 and are listed in Table 1. The calculated wavenumber of aromatic C-H stretching is to be $3054 \mathrm{~cm}^{-1}$, which observed at $3055 \mathrm{~cm}^{-1}$. The aliphatic $\mathrm{C}-\mathrm{H}$ stretching $\left(\mathrm{CH}_{2}\right.$ and $\mathrm{CH}_{3}$ groups) were performed at the range of $2965-2886 \mathrm{~cm}^{-1}$, which are in agreement with the measured assignment in the region of $2965-2884 \mathrm{~cm}^{-1}$. These results are consistent with the literature [15]. The most important stretching vibrations in the NEOPO molecule are $\mathrm{CN}$ and NO stretching vibrations were experimentally observed at 1676 and $926 \mathrm{~cm}^{-1}$, respectively, while calculated at 1623 and 923 $\mathrm{cm}^{-1}$. The other vibration modes are listed in Table 1 , and they are in agreement between calculated and experimental values.

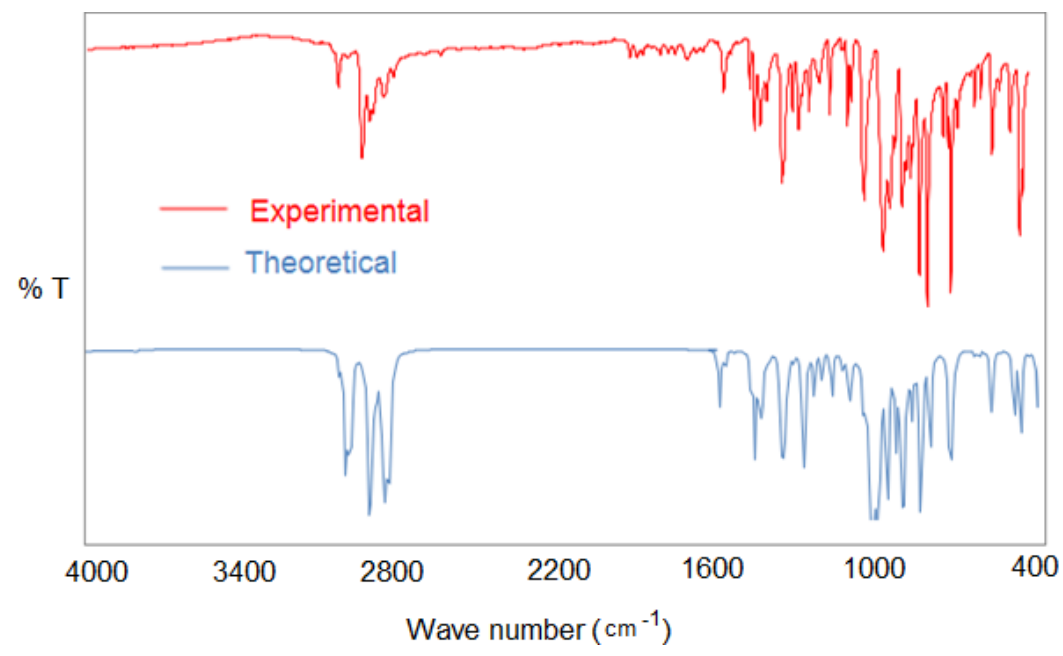

Figure 3. Experimental (red) and theoretical (blue) IR spectra of NEOPO 
Table 1. Experimental and B3LYP/6-311++G(d,p) calculated vibrational wavenumbers of NEOPO with their assignment (wavenumber in $\mathrm{cm}^{-1}$ ).

\begin{tabular}{|c|c|c|c|c|c|}
\hline Mod & Assignments & Experimental & Unscaled & Scaled & Intensity \\
\hline 19 & $\gamma \mathrm{CH}_{\text {naf }}$ & $476 \mathrm{~m}$ & 484 & 473 & 15 \\
\hline 21 & $\delta \mathrm{CC}_{\mathrm{C} 11-\mathrm{C} 12}$ & $517 \mathrm{~s}$ & 510 & 499 & 15 \\
\hline 24 & $\delta \mathrm{CC}_{\mathrm{naf}}+\delta \mathrm{NO}_{\mathrm{N} 1-\mathrm{O} 1}$ & $586 \mathrm{~s}$ & 599 & 586 & 17 \\
\hline 27 & $\delta \mathrm{CN}_{\mathrm{C} 12-\mathrm{N} 1}$ & $742 \mathrm{~s}$ & 746 & 730 & 6 \\
\hline 28 & $\gamma \mathrm{CH}_{\text {naf }}$ & $770 \mathrm{~m}$ & 760 & 743 & 43 \\
\hline 32 & $\gamma \mathrm{CH}_{\text {fen }}$ & $830 \mathrm{~s}$ & 838 & 820 & 25 \\
\hline 33 & $\gamma \mathrm{CH}_{\text {naf }}$ & & 875 & 856 & 22 \\
\hline 34 & $\delta \mathrm{CC}_{\mathrm{naf}}+\delta \mathrm{CC}_{\mathrm{C} 14-\mathrm{C} 15}$ & $861 \mathrm{~s}$ & 876 & 857 & 46 \\
\hline 36 & $\gamma \mathrm{CH}_{\text {naf }}$ & $892 \mathrm{~m}$ & 909 & 889 & 10 \\
\hline 38 & $\mathrm{vNO}_{\mathrm{N} 1-\mathrm{O} 1}$ & $926 \mathrm{~s}$ & 944 & 923 & 111 \\
\hline 40 & $\delta \mathrm{CH}_{\mathrm{naf}}+\delta \mathrm{CC}_{\mathrm{C} 10-\mathrm{C} 12}$ & $973 m$ & 973 & 952 & 17 \\
\hline 43 & $\delta \mathrm{CN}_{\mathrm{C} 12-\mathrm{N} 1}$ & $997 \mathrm{~s}$ & 1006 & 984 & 52 \\
\hline 45 & $\mathrm{vCC}_{\mathrm{C} 14-\mathrm{C} 15}$ & & 1044 & 1021 & 145 \\
\hline 47 & $\mathrm{vCO}_{\mathrm{C} 13-\mathrm{O} 1}$ & $1068 \mathrm{~s}$ & 1064 & 1041 & 298 \\
\hline 48 & $\delta \mathrm{CH}_{\mathrm{naf}}+\delta \mathrm{CH}_{\mathrm{C} 11-\mathrm{H} 1}$ & & 1097 & 1073 & 11 \\
\hline 49 & $\delta \mathrm{CH}_{\mathrm{naf}}+\delta \mathrm{CH}_{\mathrm{C} 14-\mathrm{H}+} \delta \mathrm{CH}_{\mathrm{C} 15-\mathrm{H}}$ & $1132 \mathrm{~s}$ & 1149 & 1124 & 8 \\
\hline 50 & $\delta \mathrm{CH}_{\mathrm{naf}}+\delta \mathrm{CH}_{\mathrm{C} 14-\mathrm{H}+} \delta \mathrm{CH}_{\mathrm{C} 15-\mathrm{H}}$ & & 1159 & 1134 & 6 \\
\hline 54 & $\delta \mathrm{CH}_{\text {naf }}$ & & 1223 & 1196 & 11 \\
\hline 55 & $\delta \mathrm{CH}_{\text {naf }}$ & $1235 \mathrm{~m}$ & 1262 & 1234 & 5 \\
\hline 57 & $\delta \mathrm{CH}_{\text {naf }}$ & $1277 \mathrm{~m}$ & 1292 & 1264 & 7 \\
\hline 59 & $\delta \mathrm{CH}_{\mathrm{naf}}+\delta \mathrm{CH}_{\mathrm{C} 13-\mathrm{H}+} \delta \mathrm{CH}_{\mathrm{C} 14-\mathrm{H}}$ & & 1329 & 1300 & 40 \\
\hline 63 & $\gamma \mathrm{CH}_{\mathrm{C} 11-\mathrm{H} 1}+\gamma \mathrm{CH}_{\mathrm{C} 11-\mathrm{H} 2}+\gamma \mathrm{CH}_{\mathrm{C} 11-\mathrm{H} 3}$ & $1379 \mathrm{~s}$ & 1401 & 1370 & 19 \\
\hline 64 & $\gamma \mathrm{CH}_{\mathrm{C} 13-\mathrm{H}}+\gamma \mathrm{CH}_{\mathrm{C} 14-\mathrm{H}}+\gamma \mathrm{CH}_{\mathrm{C} 15-\mathrm{H}}$ & & 1413 & 1382 & 19 \\
\hline 66 & $\gamma \mathrm{CH}_{\mathrm{C} 13-\mathrm{H}}+\gamma \mathrm{CH}_{\mathrm{C} 15-\mathrm{H}}$ & & 1420 & 1389 & 18 \\
\hline 70 & $\delta \mathrm{CH}_{\mathrm{C} 11-\mathrm{H} 1}+\delta \mathrm{CH}_{\mathrm{C} 11-\mathrm{H} 2}+\delta \mathrm{CH}_{\mathrm{C} 11-\mathrm{H} 3}$ & $1461 \mathrm{~s}$ & 1495 & 1462 & 10 \\
\hline 72 & $\gamma \mathrm{CH}_{\mathrm{C} 15-\mathrm{H} 1}+\gamma \mathrm{CH}_{\mathrm{C} 15-\mathrm{H} 2}+\gamma \mathrm{CH}_{\mathrm{C} 15-\mathrm{H} 3}$ & & 1503 & 1470 & 8 \\
\hline 74 & $\gamma \mathrm{CH}_{\mathrm{C} 13-\mathrm{H}}+\gamma \mathrm{CH}_{\mathrm{C} 14-\mathrm{H} 2}+\gamma \mathrm{CH}_{\mathrm{C} 15-\mathrm{H} 2}$ & $1483 \mathrm{~s}$ & 1523 & 1489 & 25 \\
\hline 75 & $\delta \mathrm{CH}_{\text {naf }}$ & & 1537 & 1503 & 8 \\
\hline 78 & $\mathrm{vCN}_{\mathrm{C} 12-\mathrm{N} 1}$ & $1676 \mathrm{~s}$ & 1659 & 1623 & 10 \\
\hline 80 & $\mathrm{vCH}_{\mathrm{C} 13-\mathrm{H} 1}+\mathrm{vCH}_{\mathrm{C} 13-\mathrm{H} 2}$ & $2886 \mathrm{~m}$ & 3010 & 2884 & 40 \\
\hline 81 & $\mathrm{vCH}_{\mathrm{C} 15-\mathrm{H} 1}+\mathrm{vCH}_{\mathrm{C} 15-\mathrm{H} 2}+\mathrm{vCH}_{\mathrm{C} 15-\mathrm{H} 3}$ & & 3023 & 2896 & 36 \\
\hline 82 & $\mathrm{vCH}_{\mathrm{C} 14-\mathrm{H} 1}+\mathrm{vCH}_{\mathrm{C} 14-\mathrm{H} 2}$ & & 3031 & 2904 & 46 \\
\hline 83 & $\mathrm{vCH}_{\mathrm{C} 11-\mathrm{H}}$ & & 3037 & 2909 & 11 \\
\hline 84 & $\mathrm{vCH}_{\mathrm{C} 13-\mathrm{H}}+\mathrm{vCH}_{\mathrm{C} 14-\mathrm{H}}$ & 2924w & 3043 & 2915 & 8 \\
\hline 85 & $\mathrm{vCH}_{\mathrm{C} 13-\mathrm{H}}+\mathrm{vCH}_{\mathrm{C} 14-\mathrm{H}}+\mathrm{vCH}_{\mathrm{C} 15-\mathrm{H}}$ & $2937 \mathrm{~m}$ & 3064 & 2935 & 8 \\
\hline 86 & $\mathrm{vCH}_{\mathrm{C} 11-\mathrm{H} 2}+\mathrm{vCH}_{\mathrm{C} 11-\mathrm{H} 3}$ & & 3085 & 2955 & 8 \\
\hline 87 & $\mathrm{vCH}_{\mathrm{C} 14-\mathrm{H}}+\mathrm{vCH}_{\mathrm{C} 15-\mathrm{H}}$ & & 3088 & 2958 & 77 \\
\hline 88 & $\mathrm{vCH}_{\mathrm{C} 15-\mathrm{H} 1}$ & $2965 s$ & 3093 & 2963 & 37 \\
\hline 90 & $\mathrm{vCH}_{\text {naf }}$ & $3018 v w$ & 3160 & 3027 & 5 \\
\hline 91 & $\mathrm{vCH}_{\text {naf }}$ & & 3163 & 3030 & 8 \\
\hline 92 & $\mathrm{vCH}_{\mathrm{C} 11-\mathrm{H} 1}$ & & 3164 & 3031 & 5 \\
\hline 93 & $\mathrm{vCH}_{\text {naf }}$ & & 3175 & 3042 & 25 \\
\hline 94 & $\mathrm{vCH}_{\text {naf }}$ & & 3184 & 3050 & 11 \\
\hline 95 & $\mathrm{vCH}_{\text {naf }}$ & $3055 \mathrm{~s}$ & 3188 & 3054 & 23 \\
\hline
\end{tabular}

br: broad, s:strong, m: medium, w: weak, vw: veryweak; v: streching, $\delta$ : in-planebending,

$\gamma$ : out-of- planebending, t: torsion, Scaledfactor: 0.958 for $4000-1700 \mathrm{~cm}^{-1} ; 0.978$ for $1700-400 \mathrm{~cm}^{-1}$.

The ${ }^{1} \mathrm{H}$ and ${ }^{13} \mathrm{C}$ NMR chemical shifts of the NEOPO were performed at GIAO model by using same level with TMS as a reference, and both spectra, experimental and calculated are given in Figure 4 and 5 , respectively. The chemical shifts of aromatic protons calculated between 8.56 and $7.44 \mathrm{ppm}$. These chemical shifts were measured between 8.03 and $7.51 \mathrm{ppm}$. The aliphatic protons of methyl group $(\mathrm{C} 11-\mathrm{H})$ and propyl group (C13-H, C14-H and C15-H) were measured as 2.39, 4.25, 1.83 and $1.05 \mathrm{ppm}$, respectively. These protons were calculated at 4.17-0.88 ppm. In the ${ }^{13} \mathrm{C}$ NMR spectrum of NEOPO molecule given in Figure 5 the observed $154.09 \mathrm{ppm}$ (calcd. $159.87 \mathrm{ppm}$ ) value can be assigned to oxime carbon atom (C12). The chemical shift values of aliphatic carbons are observed in the range of 75.81-12.44 ppm and these values are calculated between 79.87 and $9.77 \mathrm{ppm}$. These results are well agreed with the chemical shifts reported for similar molecules [14,16], and these results support the geometry predicted from the conformational analysis results. 


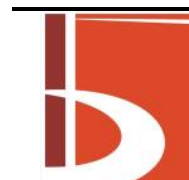

BŞEÜ Fen Bilimleri Dergisi

7. Cilt - Milli Mücadele ve TBMM'nin

Açı1ışının 100. Yılı Anısına-100. Yıl Özel

Say1s1

$175-185,2020$
BSEU Journal of Science

DOI: 10.35193/bseufbd. 632396

e-ISSN: 2458-7575 (http://dergipark.gov.tr/bseufbd)

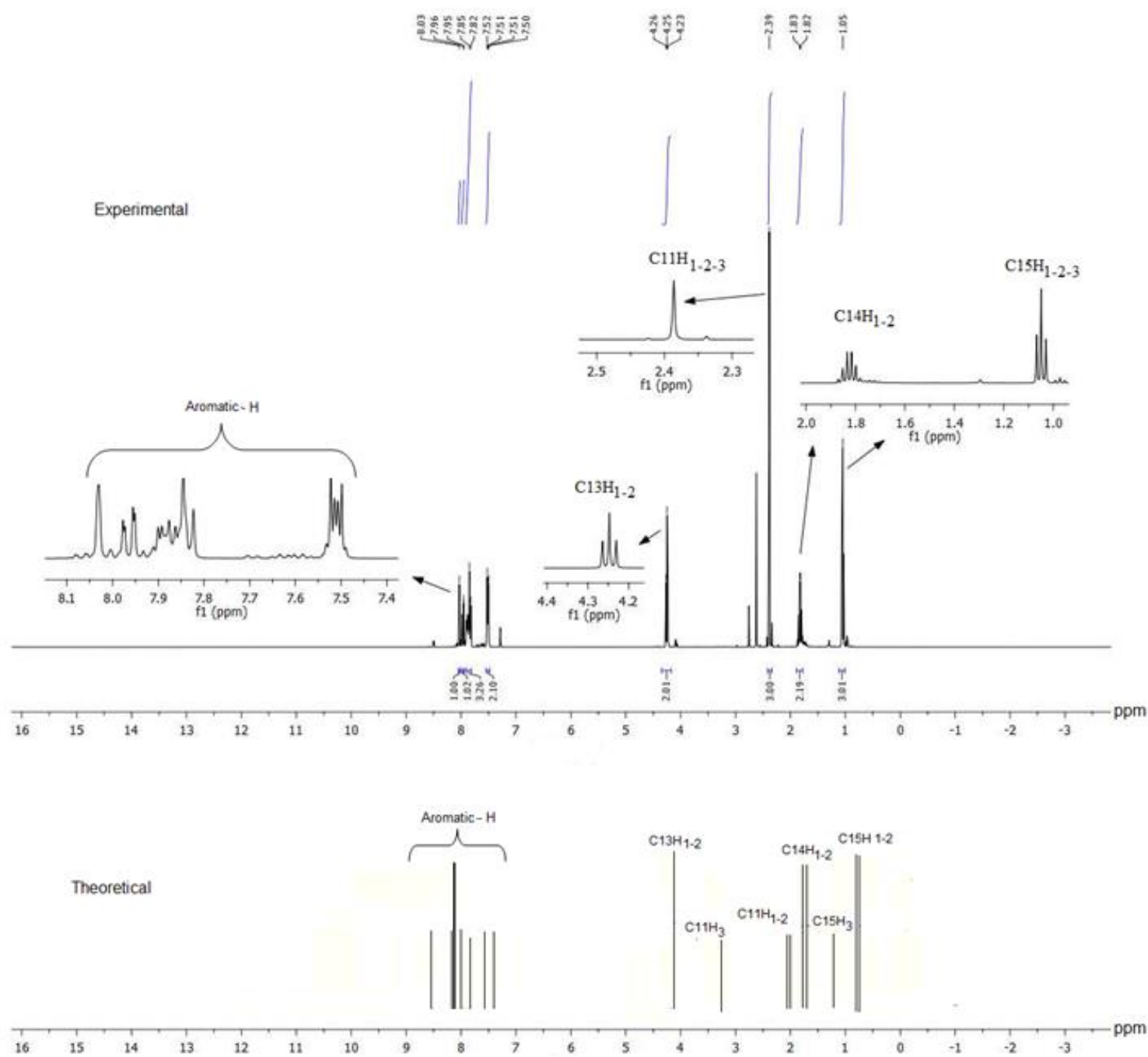

Figure 4. Experimental and theoretical ${ }^{1} \mathrm{H}$ NMR spectra of NEOPO 


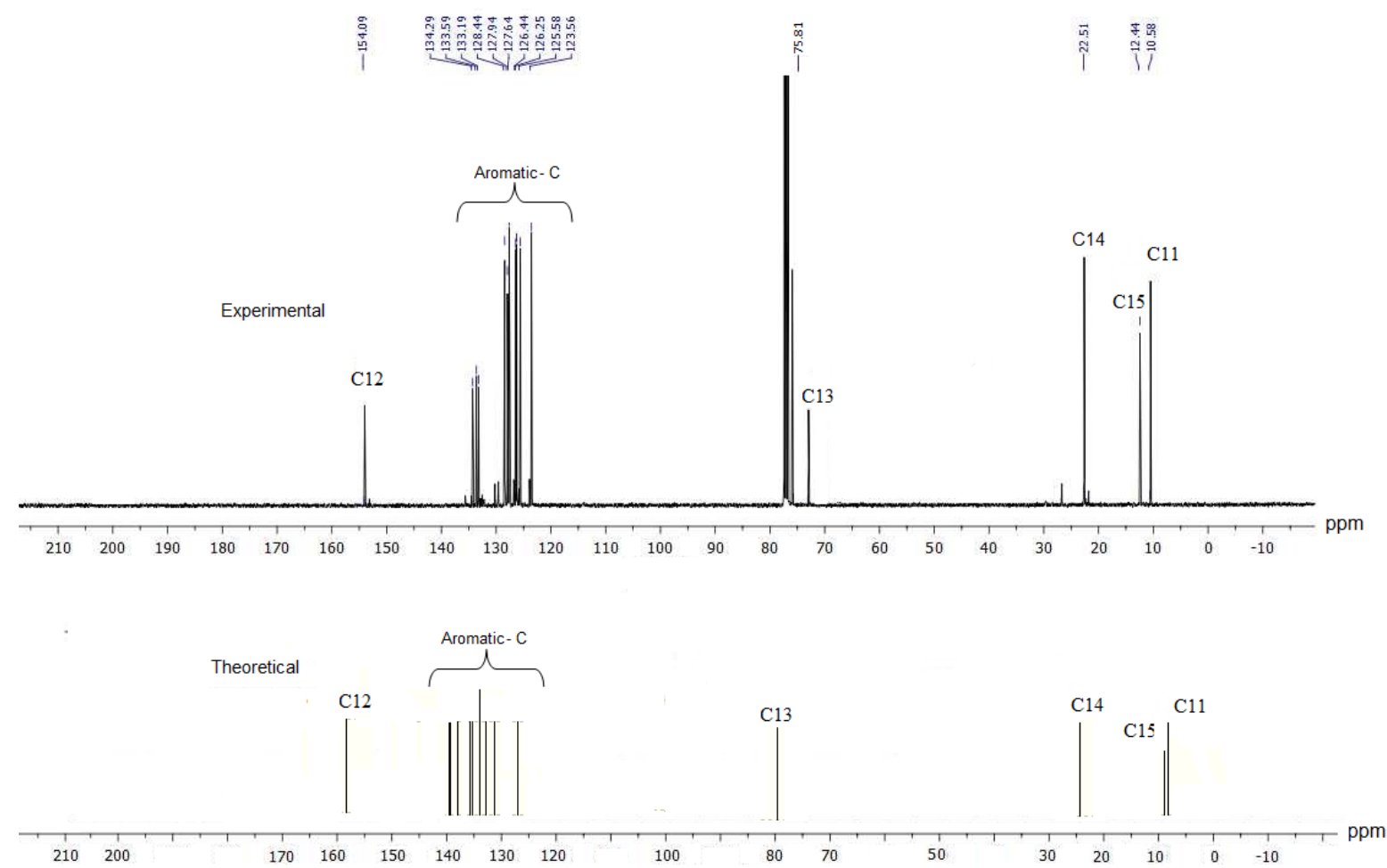

Figure 5. Experimental and theoretical ${ }^{13} \mathrm{C}$ NMR spectra of NEOPO

The maximum absorption wavelengths and excitation energy strengths calculated at Time-Dependent DFT (TD-DFT)/B3LYP/6-311++G(d,p) level and experimental values in EtOH solution are listed in Table 2. The absorption bands observed at 295, 285 and $240 \mathrm{~nm}$ in the experimental spectrum were calculated at 299, 261 and $223 \mathrm{~nm}$, respectively. These absorptions are dominantly contributed by electron excitation from HOMO to LUMO, HOMO to LUMO+1 and HOMO to LUMO+3. These orbitals have dominantly a $\pi$ character of naphtly group and thus all of these absorption bands can be ascribed to the $\pi \rightarrow \pi^{*}$ transitions.

Table 2. Experimental and calculated electronic transitions, oscillator strengths and their assignments of NEOPO

\begin{tabular}{lllllll}
\hline $\begin{array}{l}\lambda_{\max } \\
(\mathrm{nm})\end{array}$ & $\begin{array}{l}\varepsilon * 10^{-5} \\
\left(\mathrm{dm}^{3} \mathrm{~mol}^{-1} \mathrm{~cm}^{-1}\right)\end{array}$ & $\begin{array}{l}\Delta E \\
(\mathrm{eV})\end{array}$ & $\begin{array}{l}\lambda_{\max } \\
(\mathrm{nm})\end{array}$ & $\begin{array}{l}\Delta E \\
(\mathrm{eV})\end{array}$ & fos & Assignment \\
\hline & & 223 & 5.56 & 0.3010 & $\begin{array}{l}\mathrm{H}-4 \rightarrow \mathrm{L}(\% 12) \\
\mathrm{H}-2 \rightarrow \mathrm{L}(\% 25)\end{array}$ \\
240 & 3.7230 & 5.16 & 235 & 5.28 & 0.0856 & $\begin{array}{l}\mathrm{H}-2 \rightarrow \mathrm{L}(\% 19) \\
\mathrm{H} \rightarrow \mathrm{L}+3(\% 41) \\
285\end{array}$ \\
& 1.6910 & 4.35 & 261 & 4.75 & 1.0585 & $\begin{array}{l}\mathrm{H}-1 \rightarrow \mathrm{L}(\% 44) \\
\mathrm{H} \rightarrow \mathrm{L}+1(\% 48) \\
\mathrm{H} \rightarrow \mathrm{L}(\% 53) \\
\mathrm{H} \rightarrow \mathrm{L}+1(\% 22)\end{array}$ \\
\hline
\end{tabular}

$f_{\text {os }}=$ Oscillator strength, $\mathrm{H}=$ Highest occupied molecular orbital, $\mathrm{L}=$ Lowest unoccupied molecular orbital, napht = naphthalene

Frontier Molecular Orbitals, FMOs which are HOMO and LUMO, energy gap are an important and critical parameter for organic molecules. The calculated HOMO and LUMO energies of NEOPO were -5.984 and $-1.034 \mathrm{eV}$, respectively, and thus, the energy gap was $4.950 \mathrm{eV}$. The HOMO and LUMO molecular orbitals 
are presented in Figure 6 (a). In addition, this energy gap is a measure of chemical stability and explains the electrical transport properties of molecules. In this content, the molecular properties such as hardness $(\eta=(\mathrm{I}-\mathrm{A}) /$ $2)$, electronegativity $(\chi=(I+A) / 2)$, chemical potential $(\mu=-(I+A) / 2)$, softness $(S=1 / \eta)$ and electrophilicity index $\left(\omega=\mu^{2} / 2 \eta\right)$ can be calculated as $2.475,3.509,-3.509,1.238$ and $2.487 \mathrm{eV}$ respectively from energy gap [17]. Note, the negative chemical potential $(\mu)$ indicates stability, that is, the molecule will not spontaneously decompose into its elements.

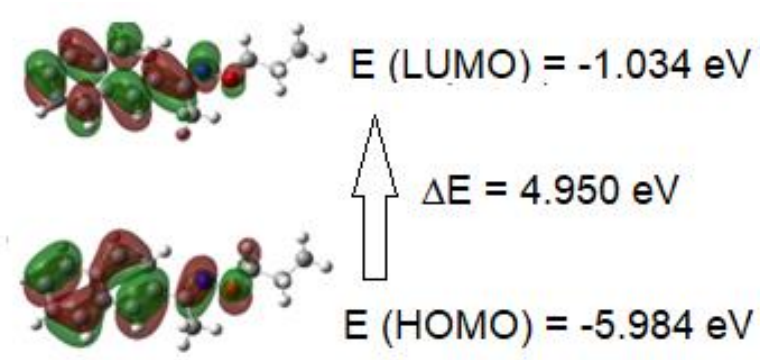

(a)

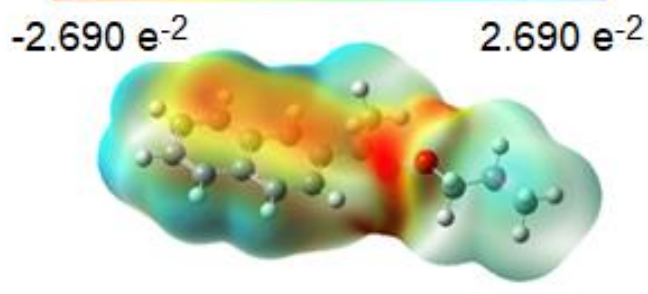

(b)

Figure 6. (a) HOMO, LUMO orbitals and band gap, (b) MEP surface of NEOPO

On the other hand, MEP is an important for the grasping the molecular interactions and provides the correlations between the molecular properties and electronegativity and chemical reactivity of molecules. The surface of the NEOPO molecule was plotted using B3LYP/6-311++G(d,p) as presented in Figure 6 (b). The color code of this map ranges from $-2.690 \mathrm{e}^{-2}$ and $+2.690 \mathrm{e}^{-2}$ a.u., where blue shows the electron deficient areas, red indicates electron rich areas, light blue slightly electron deficient areas and yellow slightly electron rich areas. Negatively charged surfaces (red and yellow) are targeted by protons or electrophiles and positive charged surfaces (blue) prefer nucleophilic attack. The MEP surface of NEOPO shows that the oxime group cover with negative charge, which are potential sites for electrophilic attack, whereas the positive charge covers naphthyl ring protons and thus, potential sites for nucleophilic attack.

The statistical thermodynamic parameters ( $C$, heat capacity, $S$, entropy and $H$, enthalpy changes) were calculated by same level from the theoretical harmonic frequencies at $1 \mathrm{~atm}$, and shown in Figure 7. As seen in Figure 7, the $\mathrm{C}, \mathrm{S}$ and $\mathrm{H}$ values are increasing with temperature rising from 100 to 1000 . The reason of this the molecular vibration intensities increases with increasing temperature [18]. The correlation equation among $\mathrm{C}, \mathrm{S}$ and $\mathrm{H}$ with temperatures was calculated and the corresponding fitting factor $\left(\mathrm{R}^{2}\right)$ is determined as 0.999 for all thermodynamic parameters as seen in in the following equations:

$$
\begin{array}{ll}
\mathrm{C}(\mathrm{J} / \mathrm{molK})=265.0900+1.0363 \mathrm{~T}-0.0002 \mathrm{~T}^{2} & \left(\mathrm{R}^{2}=0.999\right) \\
\mathrm{S}(\mathrm{J} / \mathrm{molK})=4.4373+0.9864 \mathrm{~T}-0.0004 \mathrm{~T}^{2} & \left(\mathrm{R}^{2}=0.999\right) \\
\mathrm{H}(\mathrm{kJ} / \mathrm{mol})=735.5800+0.0957 \mathrm{~T}+0.0003 \mathrm{~T}^{2} & \left(\mathrm{R}^{2}=0.999\right)
\end{array}
$$




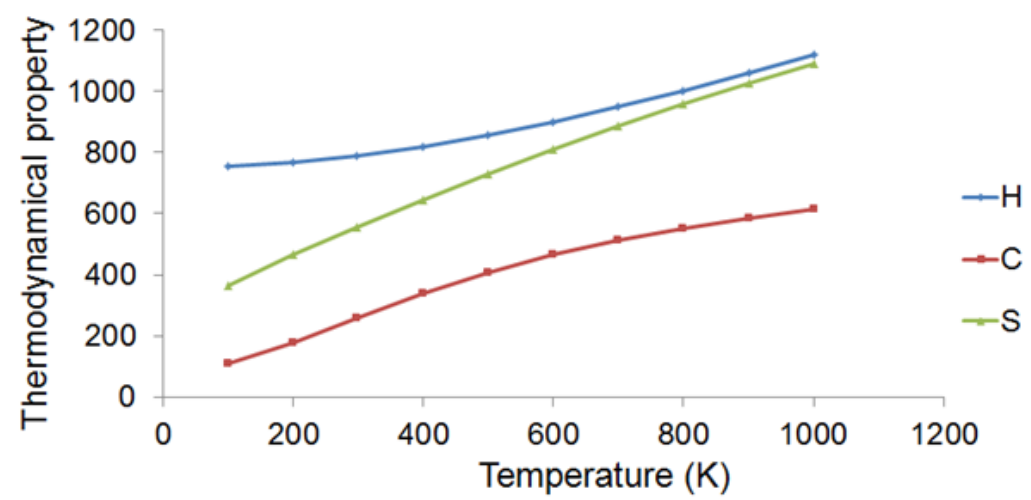

Figure 7. Graphs representing dependence of heat capacity (C), entropy (S) and enthalpy (H) on temperatures

NEOPO-DNA (PDB code: 1BNA) and NEOPO-HSA (PDB code: 1H9Z) interactions were calculated to find prefer binding mode and binding affinity using Autodock/Vina software. It is clear that NEOPO fits well into the minor groove of the targeted deoxyribonucleic acid, DNA and Guanine-Cytosine rich region stabilized by non-bonding interaction as well as van der Waals and hydrophobic contacts as seen in Figure 8 (a). In addition, the relative free binding energy of NEOPO was found to be $-27.20 \mathrm{kJmol}^{-1}$.

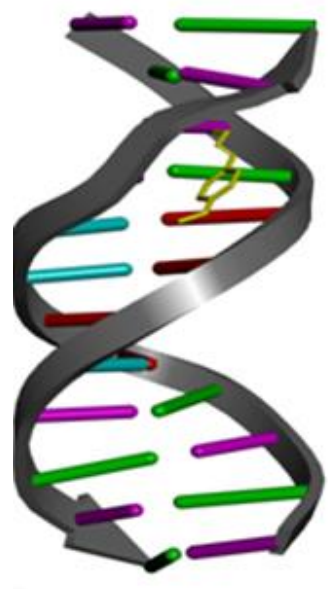

(a)

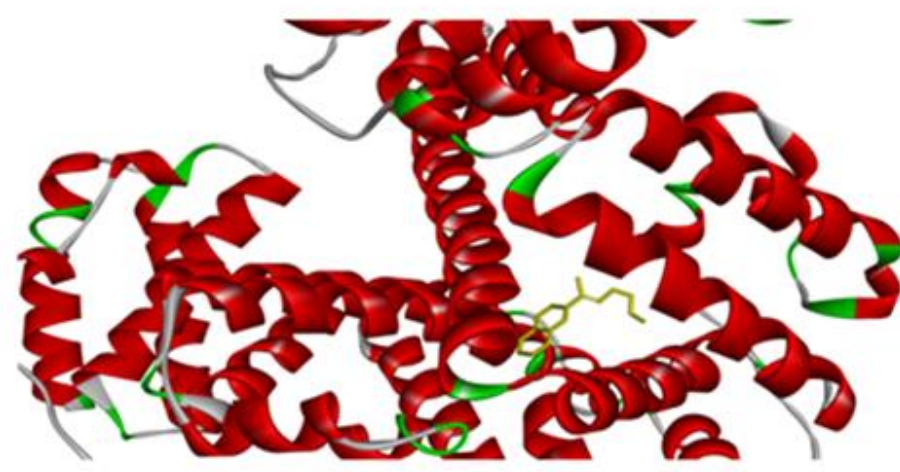

(b)

Figure 8. (a) Calculated docked pose of NEOPO (labeled yellow) with DNA. b) molecular docking of the most favorable docked structure in subdomain IIA of HSA

The best energy ranked result of NEOPO binding with Human Serum Albumin, HSA is given in Figure 8 (b). The molecular docking study of title compound and HSA showed that molecule is located within the subdomain IIA hydrophobic cavity. The free energy for docking with $1 \mathrm{H} 9 \mathrm{Z}$ was performed as $-34.73 \mathrm{~kJ} / \mathrm{mol}$.

\section{CONCLUSIONS}

In this work, quantum chemical studies, such as conformational analysis, spectroscopic properties, energy gap, MEP, thermodynamic properties and molecular docking studies of title compound were successfully studies. The conformational analysis indicated that the dihedral angles, $\alpha$ and $\beta$ of the most stable conformer were calculated $159^{\circ}$ and $179^{\circ}$, respectively. The experimental IR, NMR and UV-vis. spectra data were 
compared with theoretical values, and the results were very consistent. They support the predicted geometry from conformational analysis. In the binding process, the binding free energies of DNA docking and HSA binding were calculated at -27.20 and $34.73 \mathrm{kJmol}^{-1}$, respectively. Binding of the NEOPO to DNA through minor groove and to protein via hydrophobic interaction in subdomain IIA was determined by molecular docking studies. All of these analyses can be useful for the readers and researchers on oxime or oxime ether molecules, especially biological activities.

\section{ACKNOWLEDGMENTS}

This work is a part of a research project $171 \mathrm{~N} 10$. We thank Bursa Technical University for the financial support.

\section{REFERENCES}

[1] Zhu, X.F. Shi, D.Q. (2009) Chin. J. Chem. 27, 565.

[2] Abele, E. Lukevics, E. (2000) Org. Prep. Proc. Int. 32, 237.

[3] Mobio, I.G. Soldatankov, A.T. Fedorov, V.O. (1989) Khim. Farm. Zh. $23,421$.

[4] Krishnakumar, V. Prabavathi, N. Muthunatesan. S. (2008) Spectrochim. Acta A:Mol. Biomol. Spectr. 69,528 .

[5] Govindarajan, M. Karabacak. M. (2013) Spectrochim. Acta A: Mol. Biomol.Spectr. 101, 314.

[6] Akman, F. Durak, R. Kacal, M.R. Bezgin. F. (2016) X-Ray Spectr. 45, 103.

[7] Li, C. Zhang, H. Cui, Y. Zhang, S. Zhao, Z. Choi, M.C.K. Chan, A.S.C. (2003) Synthetic Communication 33, 543.

[8] Frisch, M. J. et al. (2010) Gaussian 09, Revision C.01, Gaussian, Inc., Wallingford CT.

[9] Becke, A.D. (1993) J Chem. Phys. 98, 5648.

[10] Foresman, J.B. Frisch, E. (1993) Exploring Chemistry with Electronic Structure Methods, Gaussian Inc., Pittsburgh, PA, USA.

[11] Sundaraganesan, N. Ilakiamani, S. Saleem, H. Wojciechowski, P.M. Michalska, D. (2005) Spectrochim. Acta. A 61, 2995.

[12] Jesus, A.J.L. Rosado, M.T.S. Reva, I. Fausto, R. Eusebio, M.E. Redinha, J.S. (2006) J. Phys. Chem. A $110,4169$.

[13] Trott, O. Olson, A.J. (2010) J. Comput. Chem. 31, 455.

[14] Kaya, Y. Yilmaz, V.T. Arslan, T. Buyukgungor, O. (2012) J. Mol. Struc. 1024, 65.

[15] Colthup, N.B. Daly, L.H. Wiberley, S.E. (1964) Introduction to Infrared and Raman Spectroscopy, Academic Press Inc., London.

[16] Kaya, Y. Yilmaz, V.T. (2014) Structural Chem. 25, 231.

[17] Parr, R.G. Yang, W. (1989) Density Functional Theory of Atoms and Molecules. New York:Oxford University Press.

[18] Bopp, F. Meixner, J. Kestin, J. (1967) Thermodynamics and StatisticalMechanics, fifth ed. Academic Press Inc. (London) Ltd., New York. 